\title{
Moderasi Pendidikan Islam dan Tantangan Masa Depan
}

\author{
Bayu Alif Ahmad Yasin Hanifatulloh
}

\begin{abstract}
This study aims to elaborate on the moderation of education and the challenges of education in the future. This study uses literature study method. The results of the study show that students are a group that is very vulnerable to being carried away by the flow of religious radicalism. A very young age and considered to be unstable, with a passionate spirit, and a strong desire to enforce religious teachings more comprehensively makes this young group who is within the scope of an educational institution to become the most vulnerable social group to be infiltrated and become the target of radical groups that convey religious understandings and attitudes that are rigid and tend to be superficial. On the other hand, new challenges have begun to emerge, such as advances in science and technology, democratization, and moral decadence that have surrounded human life in this era. So a special strategy is needed to be able to instill moderate Islamic values in students by utilizing teaching and learning activities and parenting patterns that exist in the community or in educational institutions. Because Islamic educational institutions have a moral and social burden to participate in finding the right solution or solution in order to prepare superior human resources who have strong competitiveness for the advancement and harmony of religion, nation and state.
\end{abstract}

Keywords: Moderate Islamic education, moderate Islam, Islamic education challenges

\section{Pendahuluan}

Allah SWT menciptakan Manusia dengan berbagai bentuk dan karakter. Dari perbedaan itulah, manusia sebagai makhluk ciptaan Allah SWT yang dikaruniai sebuah akal dan pikiran sehingga menyandang gelar "makhluk dengan bentuk yang sebaik-baiknya" (QS. At-Tin: 4), harus mampu menyikapi sebuah perbedaan dengan tujuan mencapai sebuah perdamaian anatar golongan. Untuk mencapai tujuan tersebut, sebagai umat yang sadar akan adanya perbedaan ditengah-tengah kehidupan manusia yang ada di dunia ini, kita harus mampu menanamkan sikap moderat atau toleransi. Moderat ini tidak hanya ada dalam Islam saja, namun diseluruh agama yang ada di muka bumi ini membutuhkan sikap moderat baik antar sesama pemeluk agama itu sendiri atau dengan pemeluk agama yang lain (Fransisca, 2019: 85). 
Begitupun dengan Pendidikan yang selalu berkembang mengiringi dinamika kehidupan manusia, pendidikan Islam sebagai bagian dari sistem pendidikan nasional, saat ini dihadapkan dengan tantangan baru sebagai konsekuensi dari dinamika zaman yang disebut era globalisasi, dalam menghadapi tantangan tersebut, diperlukan suatu strategi baru yang solutif dan antisipatif. Pendidikan Islam diartikan sebagai aktivitas dan sistem pendidikan yang diselenggarakan atau didirikan untuk mengejewantahkan nilai-nilai ajaran Islam sehingga membentuk pribadi muslim (Darajat, 1994: 28).

Indonesia merupakan negara yang dikenal dengan negara yang plural. Keragaman merupakan bagian dari ciri khas Indonesia yang mesti disikapi dengan cara yang baik dan tepat oleh setiap warga negara sehingga dapat menjadi warna yang bisa memperluas khazanah peradaban bangsa Indonesia. Walaupun keragaman sudah menjadi realitas yang disadari oleh segenap warga negara, namun dalam menyikapi segala macam persoalan yang ada mengenai keragaman warga negara masih sering kali menimbulkan konflik, apalagi ketika keragaman dan perbedaan tersebut berkaitan dengan keyakinan agama. Keyakinan terhadap agama yang dianut oleh seseorang acap kali menutup peluang akan adanya kebenaran yang muncul pada keyakinan yang lainnya. Pada tahap ini, klaim terhadap kebenaran agama yang dianutnya (truth claim) akan menjadi alat penghakiman (judgment) terhadap "kesesatan" pada keyakinan yang lain. Latar belakang kesadaran teologis yang seperti itu dapat memicu dan mengembangkan permasalahan dalam aspek sosial yaitu munculnya intoleransi dan gerakan radikal (Hermawan, 2015: 32).

Menurut Azyumardi Azra yang dikutip Yunus dalam jurnalnya, menyampaikan bahwa untuk membangun hubungan yang harmonis antar umat beragama dan menciptakan suasana inklusif dalam beragama dibutuhkan kemampuan dari setiap kelompok keagamaan untuk mendalami pemahaman mutual atas doktrin-doktrin dan praktik-praktik kelompok keagamaan lain sebagai prioritas pertama, dalam artian hal ini dilakukan sebagai bentuk pendalaman terhadap pengenalan kemajemukan terhadap aspek tafsir ajaran keagamaan (Yunus, 2018: 188).

Moderasi Islam merupakan wacana penting pada abad ini, mengingat maraknya konflik yang terjadi di internal umat Islam saat ini. Problem yang dihadapi umat Islam saat ini sangat kompleks, mulai dari masalah sosial, budaya dan agama. Masalah sosial yang dihadapi oleh umat Islam saat ini adalah kurangnya kesadaran hidup bertoleransi. Umat Islam sekarang cenderung tidak peduli terhadap keberadaan orang lain, seakan-akan mereka tidak membutuhkannya. Sementara itu budaya merupakan bagian dari problem yang dihadapi umat Islam sekarang. Budaya Islam sekarang tidak menarik lagi bagi umat Islam, khususnya kalangan anak muda. Mereka lebih senang dengan budaya barat, yang notabene memiliki paham kebebasan atau 
liberal. Paham seperti ini jelas akan membahayakan generasi umat Islam di masa mendatang (Mubarok, 2018: 165).

Dalam akhir-akhir ini, pemahaman tentang Islam radikal mulai terasa semakin menguat dengan ditandai dengan banyaknya kasus intoleransi dalam lingkungan masyarakat maupun di dunia pendidikan atau sekolah. Hal ini tentu saja menjadi persoalan yang mesti segera ditangani karena dikhawatirkan akan merusak konstruksi sosial masyarakat Indonesia yang dikenal dengan keragamannya atau multikultur. Permasalahan akan semakin rumit dan mengkhawatirkan apabila paham radikal dan intoleransi agama juga telah menjangkiti pada siswa di sekolah, karena merekalah yang nantinya menjadi penentu dan penerus masa depan bangsa Indonesia (Hermawan, 2015: 32).

Instalasi penguatan paham Islam moderat dalam lembaga pendidikan Islam sangat perlu dilakukan. Karena peran dunia pendidikan dapat diplot sebagai salah satu institusi yang dapat dioptimalisir untuk melakukan apa yang disebut dengan deradikalisasi. Peran pendidikan Islam terutama yang dikelola langsung oleh sebagian besar umat Islam diharapkan dapat melakukan perannya tersebut dengan baik, bersama institusi lainnya, sehingga wajah Islam di Indonsesia khususnya tetap terlihat ramah, toleran, moderat, namun tetap memiliki martabat di mata dunia. Oleh karena itu, lembaga pendidikan Islam sangat memiliki andil dan peran strategis bagi penguatan karakter moderat ini (Suharto, 2017: 166).

Sebuah penelitian yang dilakukan oleh Pusat Pengkajian Islam dan Masyarakat (PPIM) UIN Syarif Hidayatulloh Jakarta pada tahun 2017 kepada guru, dosen, siswa, dan mahasiswa di 34 provinsi di Indonesia menunjukan bahwa, siswa dan mahasiswa memiliki kecenderungan pada pandangan keagamaan yang intoleran dengan persentase opini radikal sebanyak $58 \%$, opini intoleransi internal 51,1\%, dan opini intoleransi eksternal 34,3\% (PPIM UIN Jakarta, 2017: 3). Data ini menyajikan pemahaman kepada kita tentang angka munculnya bibit radikalisme dan intoleransi benar-benar telah memperlihatkan eksistensinya dan telah menjangkiti para siswa di sekolah. Maka dari itu, guru dan dosen atau tenaga keoendidikan di sekolah memiliki potensi untuk membentuk radikalisme di kalah siswa atau mahasiwanya, karena latar belakang opini atau pemahaman yang dimiliki pengajarnya sangat berpotensi menularkan pemahaman kepada para siswanya (Hermawan, 2015: 32).

Kondisi di atas memunculkan pertanyaan besar tentang bagaimana nilai-nilai moderasi islam yang menjadi mainstream pemahaman agama Islam yang ada di Indonesia mampu mendapatkan tantangan besar dari paham radikal dan intoleransi? Bagaimana sesungguhnya peran lembaga pendidikan mengambil peran dan memberikan fasiltas penyebaran dan penanaman nilai moderasi Islam? Tulisan ini akan menganalisis beberapa hal yang mampu dilakukan oleh lembaga pendidikan Islam dalam menginternalisasikan nilai moderasi Islam juga dalam menghadapi tantangan masa depan dan 
memberikan perspektif penguatan yang dapat dijadikan sebagai alternatif dalam memberikan pemahaman ajaran Islam yang moderat (Hermawan, 2015: 32).

\section{Metode}

Kajian ini menggunakan metode riset kepustakaan, di mana literaturliteratur primer dan sekunder dianalisis secara kritis untuk memperoleh gambaran tentang moderasi pendidikan Islam dan tantangan yang akan dihadapinya di masa yang akan datang.

\section{Hasil dan Pembahasan}

\section{Moderasi Pendidikan Islam}

Moderasi merupakan ajaran inti agama Islam. Islam moderat adalah paham keagamaan yang sangat relevan dalam konteks keberagaman dalam segala aspek, baik agama, adat istiadat, suku dan bangsa itu sendiri. Moderat dalam arti al-wasath sebagai model berpikir dan berinteraksi secara seimbang diantara dua kondisi, sehingga sesuai dengan prinsip-prinsip Islam dalam berakidah, beribadah, dan beretika setidaknya bisa dilihat kesesuaiannya dengan pertimbangan-pertimbangan dalam berprilaku yang senantiasa mengacu pada maqasid al-syari'ah (Yunus, 2018: 189).

Sikap moderat sangatlah penting untuk menyimpul keberagaman kelompok, ras, etnik, budaya di negara Indonesia yang sudah pasti akan menimbulkan perbedaan di setiap kelompok tersebut. Dengan bersikap moderat, berarti kita juga turut mengaplikasikan dasar negara yang termaktub dalam Pancasila sila ke-2 yang berbunyi "kemanusiaan yang adil dan beradab". Adil yang berarti menempatkan sesuatu sesuai dengan tempatnya atau tidak berbuat zalim. Beradab berarti memiliki etika bagaimana cara kita memperlakukan orang lain atau menghormati orang lain di atas perbedaan yang kita miliki, seperti lebih memilih perdamaian dalam sebuah pertikaian (lisan maupun fisik), yang mana merupakan tujuan dari moderat itu sendiri (Fransisca, 2019: 85).

Pemahaman paling mendasar dalam mengenal moderatisme yang diajarkan oleh Islam tergambar dari pemaparan yang ada dalam al-Quran. AlQuran pada umumnya menggunakan istilah al-wasathiyyah untuk menjelaskan makna moderat dalam Islam. Walaupun sebenarnya sangat banyak perbedaanperbedaan dalam pemahaman moderat pada konteks saat ini. Oleh sebab itu pemahaman dasar ini bisa dijadikan akar dalam memahami moderasi Islam sebenarnya (Zamimah, 2018: 80).

Kata al-wasathiyyah berakar pada kata al-wasth (dengan huruf sin yang disukunkan) dan al-wasath (dengan huruf sin yang difathahkan) yang keduanya merupakan mashdar dari kata kerja (fi'il) wasatha. Secara sederhana, pengertian Wasathiyyah secara terminologis artinya suatu karakteristik terpuji yang menjaga seseorang dari kecenderungan bersifat ekstrim (Zamimah, 2018: 
81). Dalam buku strategi al-wasathiyyah yang diterbitkan oleh kementrian wakaf dan urusan agama Islam Kuwait dan dikutip oleh Mukhlis Hanafi, wasathiyyah didefiniskan sebuah metode berpikir, berinteraksi, dan berperilaku yang didasari atas sikap tawaazun (seimbang) dalam menyikapi dua keadaan perilaku yang dimungkinkan untuk dianalisis dan dibandingkan, sehingga dapat ditemukan sikap yang sesuai dengan kondisi dan tidak bertentangan dengan prinsip-prinsip ajaran agama dan tradisi masyarakat (Zamimah, 2018: 81).

Yusuf Al-Qardhawi menjelaskan, wasathiyyah yang dapat disebut juga dengan at-tawaazun, yaitu upaya menjaga keseimbangan antara dua sisi/ujung/pinggir yang berlawanan atau bertolak belakang; spiritualisme, materialisme, individualisme, dan sosialisme, paham yang realistik dan yang idealis, dan lain sebagainya. Bersikap seimbang dalam menyikapi masalah yaitu dengan memberi porsi yang adil dan proporsional kepada masing-masing sisi/pihak tanpa berlebihan, baik karena terlalu bianyak ataupun terlalu sedikit (Zamimah, 2018: 82).

Agama Islam berpesan dalam banyak ayat al-quran dan hadits tentang perbedaan dan keragaman, perbedaan dan keragaman sesungguhnya merupakan kehendak sang maha Pencipta Allah swt sendiri (Shihab, 2007: 52). Sehingga pemahaman tentang pluralitas semestinya sudah menjadi bagian yang menyatu dalam kesadaran teologis setiap umat Islam. Kesadaran tentang keragaman ini pada gilirannya juga akan mengarahkan pada pemahaman dan sikap yang moderat dalam beragama. Karena setiap perbedaan pasti akan menimbulkan persinggungan dan gesekan, namun dengan adanya sikap moderat dalam beragama akan menjadikan perbedaan dan keragaman sebagai sebuah realitas yang tidak perlu dipertentangkan, justru mesti dikelola dengan baik sehingga menjadi sumber kekayaan khazanah sosial yang yang ada. Pada titik inilah kita bisa merasakan kebenaran bahwa perbedaan dan keragaman merupakat rahmat dan berkah bagi kehidupan manusia (Hermawan, 2015: 33).

Konsep moderasi dalam Islam dikenal dengan istilah wasathiyah yang bersumber dari al-Quran. Al-Quran menyebut umat islam sebagai ummatan wasathan (al-Baqarah: 143). Pada kerangka ini sesungguhnya bersikap moderat merupakan karakter utama dari seorang muslim (Suharto, 2014: 88). Menurut al-Qhardhawi, wasathiyah adalah sesuatu yang memerlukan hak yang sepatutnya, yaitu dengan memberikan hak yang sewajarnya dengan mengambil jalan tengan agar tidak melampaui batas-batas ajaran Islam (Qardhawi, 1997: 10). Dalam konteks Indonesia, sikap moderat dapat tercermin dalam karakter sebagai berikut; 1) penyebaran ajaran Islam melalui ideologi non kekerasan, 2) mengadopsi cara hidup modern dengan segala derivasinya, termasuk teknologi, demokrasi, HAM, dan sejemisnya, 3) penggunaan cara berpikir rasional, 4) memahami Islam dengan pendekatan kontekstual, dan 5) penggunaan ijtihad dalam mencari solusi terhadap persoalan yang tidak ditemukan justifikasinya dalam al-Quran dan hadits (Hilmy, 2013: 25). 
Untuk menopang konsep dan sikap moderat, setidaknya ada empat prinsip dasar yang harus dikembangkan dan diinternalisasikan melalui proses pendidikan. Keempat nilai dasar tersebut ialah toleransi (tasamuh), keadilan (i'tidal), keseimbangan (tawazzun), dan persamaan (Hermawan, 2015: 34). Pendidikan agama dimaksudkan untuk peningkatan potensi spiritual dan membentuk peserta didik yang kelak menjadi manusia yang beriman dan bertaqwa kepada Tuhan yang maha Esa dan berakhlak mulia. Akhlak mulia mencakup etika, budi pekerti, dan moral sebagai bentuk perwujudan dari pendidikan agama (Yunus, 2018: 185)

Bila ditelusuri secara menyeluruh, bisa dipahami bahwa pendidikan Islam yang berkarakter Moderat (tawasuth) merupakan pendidikan yang berdasarkan pada prinsip toleransi (tasamuh), menempuh jalan tengah serta berimbang (tawazun) dan netral (ta'adul) dalam menyelsaikan berbagai permasalahan yang ada, dan bertujuan untuk menciptakan kemashlahatan. Dengan demikian ditantang untuk menegaskan interpretasi yang benar, argumentatif dan kokoh dalam menghadapi perkembangan zaman. Sehingga Islam moderat akan mampu mendudukan keadilan di atas berbagai tindak kezaliman dalam ruang lokal dan global (Alam, 2017: 34).

Peningkatan potensi spiritual mencakup pengamalan, pemahaman, dan penanaman nilai-nilai keagamaan, serta pengamalan nilai-nilai tersebut dalam kehidupan individual atau kolektif kemasyarakatan. Peningkatan potensi spiritual tersebut pada akhirnya bertujuan untuk pengoptimalisasian berbagai potensi yang diperoleh manusia yang aktualisasinya mencerminkan harkat dan martabatnya sebagai makhluk Allah SWT. Oleh karena itu, pendidik diharapkan mampu mengembangkan metode pembelajaran dan pola pengasuhan sesuai dengan standar kompetensi dan kompetensi dasar yang telah ditentukan (Yunus, 2018: 185).

Konsep moderasi pendidikan Islam merupakan salah satu karakteristik Islam yang tidak dimiliki oleh agama-agama lain. Moderasi pendidikan Islam ini menyeru kepada dakwah Islam yang toleran, menentang segala pemikiran yang liberal dan radikal. Liberal dalam artian memahami Islam dengan standar hawa nafsu dan logika murni yang cenderung mencari pembenaran yang tidak ilmiah, radikal dalam arti memaknai Islam secara tekstual dan menghilangkan fleksibilitas ajarannya, sehingga terkesan kaku dan tidak mampu membaca realitas hidup (Mubarok, 2018: 166).

Dengan mengimplementasikan pendidikan Islam moderat dan bertindak rasional, diyakini akan mampu mencegah, menangkal, dan menanggulangi segala macam ancaman radikalisme dan ekstrimisme, mengembangkan sikap tidak berlebihan, suka kepada hal yang sedang-sedang serta menjauhi segala macam perbuatan yang dikhawatirkan akan menimbulkan kemadharatan di tengah masyarakat. Hal ini dianggap sangat penting karena selaras dengan kaidah bahwa "mencegah kerusakan mesti didahulukan daripada memperbaiki setelah terjadi kerusakan" atau 
"pencegahan itu lebih baik dilakukan daripada memperbaiki, mencegah terjadinya penyakit lebih baik daripada mengobati suatu penyakit" begitupun dengan hal mengantisipasi terjadinya perbuatan kekerasan sejak dini lebih baik daripada melerai perbuatan kekerasan yang sudah terjadi secara luas. Maka dengan sikap yang demikian diyakini akan melahirkan sikap persaudaraan yang seimbang antara persaudaraan sesama agama (Ukhuwah Islamiyah), dengan persaudaraan antar sesama bangsa (Ukhuwah Wathaniyah), begitu juga dengan persaudaraan antar sesama umat manusia (Ukhuwah Basyariyah) (Alam, 2017: 34).

Pada hakikatnya hubungan persaudaraan dan toleransi anatara umat beragama sama sekali tidak dilarang oleh Islam, selama masih dalam dalam tataran kemanusiaan dan kedua belah pihak saling menghormati hak-haknya masing-masing. Toleransi meniscayakan sebuah cakrawala yang luas untuk memahami orang lain, karena dengan pemahaman tersebut akan memudahkan jalan untuk mengenali dan menjalin kerjasama. Salah satu jalan untuk mencapai peradaban toleransi ini adalah melalui inklusifisme. Sikap inklusif akan mengajarkan kepada kita tentang kebenaran yang bersifat universal sehingga dengan sendirinya juga akan mampu mengikis sedikit demi sedikit paham eksklusif yang melihat kebenaran dan kemuliaan hanya ada pada diri dan pihaknya sendiri. Kebenaran sangat mungkin sekali ada dan dimiliki oleh orang lain (Misrawi, 2010: 178).

Kerja sama dari berbagai elemen-elemen yang terkait seperti pemerintah, lembaga pendidikan, dan seluruh masyarakat sudah semestinya menjadikan ideologi yang ada sebagai pemersatu yang paling kuat, juga mampu menyadarkan, mengembalikan keadaban, keseimbangan, akal sehat dan hati nurani, tidak gelap mata, menghilangkan kebencian, tindakan yang tidak beradab, keji dan mungkar. Memang diakui, yang menjadi landasan penting bagi Islam moderat di Indonesia adalah prinsip tasamuh, yang memiliki dimensi yang toleransi, tawasuth yang mendudukan kemoderatan pada situasi yang sepantasnya dan i'tidal, yang memiliki dimensi kemashlahatan, kedamaian, dan keadilan (Alam, 2017: 35).

Dalam mempertahankan prinsip ini dibutuhkan pemikiran yang segar dan cemerlang, tidak hanya berkutat pada teks kanonik yang masyhur disebut dengan "kitab kuning", tetapi juga harus diperkaya dengan keilmuan-keilmuan yang mutakhir dan mampu membaca persoalan yang muncul baik dalam area lokal ataupun global serta mampu menyelesaikannya dengan konsep Islam moderat yang berlandaskan tridimensi ukhuwah keagamaan (Islamiyah, kebangsaan (wathaniyah), dan kemanusiaan (basyariyah) benar-benar mengglobal (Alam, 2017: 36).

Pendidikan Islam moderat diharapkan mampu disosialisasikan kepada masyarakat secara masif, dan diinternalisasikan, diimplementasikan, bahkan harus sampai ke titik traninternalisasi, sehingga terwujudnya sebuah sikap 
mental atau kepribadian yang seirama, dan menjadi watak yang berlaku secara istiqomah dan sulit digoyahkan oleh situasi apapun (Muhaimin, 2004: 179).

Dalam menghadapi masyarakat yang majemuk, pluralisme, keragaman dan keaneka ragaman, senjata yang paling ampuh untuk mengatur agar tidak terjadi radikalisme, bentrokan dalam memenuhi kebutuhan hidup adalah melalui pendidikan Islam moderat dan inklusif. Apalagi dewasa ini ketika gelombang persoalan yang menerpa bangsa Indonesia kian kuat, kesadaran bersama itu semakin dibutuhkan, dan dapat terawat dengan baik. Sudah sangat sering kita menyaksikan fenomena negatif populisme, ekstrimisme yang mendukung, menyuburkan rasisme, xenophobia, anti sematisme, otoritarianisme, fanatisme, ini merupakan konservatisme agama, yang akan melahirkan perilaku ambivalensi. Praktik-praktik demikian sesuangguhnya sudah sangat mencemari wajah agama yang sejatinya adalah menjadi jalan untuk membuka keselamatan, kemashlahatan, perdamaian, dan persatuan (Alam,2017: 37).

\section{Tantangan Pendidikan Islam Masa Depan}

Dalam waktu dekat ini ancaman dan tindakan radikal, ekstrim sering bermunculan yang dilakukan oleh kelompok-kelompok tertentu, yang mampu meresahkan masyarakat dan juga mengancam pilar-pilar kewarganegaraan yang mengikat kita bersama dalam sebuah bingkai negara kesatuan. Mereka tergolong pada kelompok aliran keras yang fanatik, keras kepala, kasar, selalu berprasangka buruk, berpandangan sempit, dan cenderung kaku. Seolah-olah ruang keberagamaan di negara kita seakan pengap dengan kekerasan dan kebrutalan. Kelompok ini mengartikan jihad dengan perang, padahal jihad bukan hanya berarti perang saja, tetapi berusaha dengan sungguh-sungguh untuk memperbaiki masyarakat, dan Islam merupakan agama yang mencintai kedamaian (Alam, 2017: 24).

Ketika globalisasi dihadapkan dengan pendidikan Islam, maka akan muncul dua implikasi sekaligus, yakni peluang dan ancaman. Sebagai peluang, globalisasi di satu sisi akan memudahkan pendidikan Islam untuk mengakses berbagai macam informasi dengan cepat, juga memudahkan pendidikan Islam untuk menyebarluaskan produk-produk keilmuan yang sangat memberikan manfaat bagi masyarakat. Kemudian sebagai ancaman, globalisasi tidak hanya mempengaruhi tatanan kehidupan pada tatanan makro, tapi juga mengubah tata kehidupan pada level mikro, yakni terhadap ikatan kehidupan sosial masyarakat. Globalisasi memicu fenomena disintegrasi sosial, hilangnya nilainilai tradisi, adat istiadat, sopan santun, dan penyimpangan sosial lainnya (Zubaedi. 2012: 54).

Menurut Mastuhu, yang dikutip Pewangi dalam jurnalnya mengemukakan, beberapa tantangan yang dihadapi dunia pendidikan masa kini, yaitu globalisasi, kompleksitas, turbulence, dinamika, akselerasi, keberlanjutan dari yang kuno ke arah modern, koneksitas, konvergensi, 
konsolidasi, rasionalisme, paradoks global, dan kekuatan pemikiran (Mastuhu, 1999: 5). Selanjutnya, secara eksternal masa depan pendidikan Islam dipengaruhi oleh tiga unsur besar, yaitu globalisasi, demokratisasi, dan liberalisme Islam (Rahim. 2001: 14). Menurut Daulaytantangan pendidikan Islam masa kini dan masa depan adalah globalisasi, kemajuan ilmu pengetahuan dan teknologi, dan dekadensi moral. Sedangkan menurut Wahid mengatakan bahwa tantangan pendidikan Islam masa kini dan masa depan adalah kebodohan, kebobrokan moral, dan hilangnya karakter muslim (Pewangi: 5).

Keempat pakar di atas berbeda dalam mengidentifikasi tantangan pendidikan Islam karena berbeda sudut pandang yang digunakan. Mastuhu melihatnya dari perspektif perubahan sosial, Rahim mengamati dari tinjauan politik, Daulay melihatnya dari sudut perkembangan iptek, dan Wahid melihatnya dari sudut pandang etika.

Merujuk pada pendapat-pendapat para pakar di atas, penulis memilih dan merumuskan tiga tantangan utama untuk dikaji. Ketiga tantangan ini dianggap memiliki pengaruh yang sangat krusial bagi pendidikan Islam. Adapun tantangan yang lainnya merupakan implikasi yang lahir dari adanya ketiga tantangan utama tersebut.

1. Kemajuan Ilmu Pengetahuan dan Teknologi

Pendidikan Islam dewasa ini sedang ditantang eksistensinya terhadap pembentukan peradaban dan budaya modern yang relevan dengan perkembangan ilmu pengetahuan dan teknologi. Pada dimensi ini, banyak pendapat yang mengatakan bahwa pendidikan Islam mengalami kemunduran fungsi (degradasi fungsi) karena pendidikan Islam lebih berorientasi pada aspek moral spiritual, tidak terlalu fokus memprioritaskan aspek yang bersifat praktisdan pragmatis, seperti penguasaan teknologi. Akibatnya, pendidikan Islam kurang mampu bersaing pada level kebudayaan di tingkat global. Secara makro kondisi pendidikan Islam saat ini sudah ktinggalan zaman. Tertinggal karena kalah berpacu dengan perkembangan san perubahan sosial budaya. Tertinggal dalam penguasaan ipteks yang mengalami beragam kemajuan bersifat fasilitatif terhadap kekehidupan manusia. Artinya, ipteks memberikan fasilitas kemudahan bagi manusia, juga mampu merugikan manusia (Pewangi: $6)$.

Sesuai dengan uraian di atas, dapat disimpulkan bahwa pendidikan Islam memandang perkembangan ilmu pengetahuan dan teknologi sebagai tantangan yang harus dihadapi dan dikuasai, sehingga generasi penerus muslim tidak tertinggal oleh perkembangan ilmu pengetahuan dan teknologi yang terus berkembang. Pada konteks ini ada dua hal penting yang harus dipikirkan, adalah: 1) bagaimana supaya perkembangan ilmu pengetahuan dan teknologi tidak terlepas dari nilai-nilai ajaran Islam; 2) bagaimana pendidikan Islam dapat berkontribusi bagi kemajuan ilmu pengetahuan dan teknologi di masa depan. 


\section{Demokratisasi}

Demokratisasi merupakan isu lain yang mempengaruhi pendidikan Islam Indonesia. Tuntutan demokratisasi ini pada awalnya ditujukan pada sistem politik negara sebagai antitesis terhadap sistem politik yang otoriter. Selanjutnya perkembangan tuntutan ini mengarah kepada sistem penngelolaan berbagai bidang termasuk bidang pendidikan. Kehidupan demokrasi merupakan kehidupan yang saling menghargai akan potensi individu. Artinya, bahwa seyiap bentuk homogenisasi masyarakat adalah bertentangan dengan prinsip-prinsip hidup demokrasi. Sehingga, dalam bidang pendidikan semua warga negara memiliki hak yang sama untuk memperoleh pendidikan, juga memiliki kewajiban yang sama dalam membangun pendidikan nasional yang berkualitas. Demokratisasi pendidikan membuka ruang partisipasi publik untuk terlibat langsung dalam pendidikan. Demokratisasi pendidikan Islam ini menghendaki sistem pendidikan yang bersifat sentralistik, seragam, dan dependen, untuk beralih mengembangkan sistem pendidikan yang lebih otonom, beragam, dan independen (Pewangi: 7).

3. Dekadensi Moral

Revolusi teknologi berakibat pada pergeseran nilai dan norma budaya. Pada lazimnya, nilai-nilai budaya dari pihak yang lebih dominan dalam penguasaan ilmu pengetahuan dan teknologi (IPTEKS) akan cenderung berposisi dominan pula dalam interaksi kultural yang terjadi. Dalam konteks ini, budaya barat telah memperlihatkan eksistensinya yang superior terhadap budaya Islam. Produk teknologi seperti TV, handphone, internet, dan lainnya yang dapat membuka hubungan dengan dunia luar dengan mudah sehingga wawasan masyarakat terbuka. Namun, lewat media tersebut dapat pula disaksikan pornografi, film-film, sinetron yang menawarkan gaya hidup bebas, dan juga kekerasan yang secara moral bertentangan dengan nilai ajaran Islam.

Islam secara normatif-doktrinal, secara tegas menepis dan menolak sikap eksklusif. Dengan cara menawarkan solusi-solusi yang lebih bersifat realistik, praktis, konstruktif, dan kondusif agar menumbuhkan iklim tenggang rasa, simpati, dan toleransi antara satu kelompok dengan kelompok lainnya (Abdulloh, 2000: 75). Dalam hidup yang penuh kemajemukan hendaknya ada kesediaan untuk menerima kelompok lain secara sama sebagai kesatuan, tanpa memandang perbedaan budaya, etnik, gender, bahasa maupun agama. Karena itu merupakan salah satu bentuk pertalian sejati kebhinekaan dalam sebuah ikatan-ikatan keadaban dan juga merupakan suatu keharusan bagi seluruh umat manusia (Alam, 2017: 24).

Dalam menghadapi tantangan masa depan, dengan mengedepankan penanaman prinsip pendidikan Islam moderat di wilayah lembaga pendidikan akan membuahkan hasil yang baik, dan mampu memberikan kontribusi yang positif. Karena apabila ditelusuri secara menyeluruh, dapat diketahui bahwa pendidikan Islam yang berkarakter moderat (tawasuth) merupakan pendidikan yang berdasarkan pada prinsip toleransi (tasamuh), menempuh 
jalan tengah yang berimbang (tawazun), dan netral (ta'adul) dalam menyelesaikan segala permasalahan yang dihadapi, serta bertujuan untuk lebih mewujudkan kemashlahatan bagi umatnya (Alam, 2017: 25).

Kegagalan dalam menumbuh kembangkan sikap toleran dan inklusif dalam pendidikan agama. Hanya akan melahirkan sayap radikal dalam beragama. Menurut filsafat pendidikan Paulo Freire "Sudah saatnya pendidikan Islam diarahkan pada arena pembebasan dari belenggu doktrin-doktrin agama yang eksklusif dan intoleran. Menuju formulasi pendidikan agama yang moderat dan inklusif. Menurut Burhani sebagaimana dikutip oleh Yunus dalam jurnalnya, Pendidikan harus diarahkan untuk proses kemerdekaan, bukan menjinakkan budaya yang serba eksklusif. Sebab cara pandang atau pemahaman teologis yang eksklusif dan intoleran pada gilirannya akan dapat merusak harmonisasi agama-agama dan menghilangkan sikap untuk saling menghargai kebenaran dari agama lain. Disinilah sikap moderat menuai relevansinya, sehingga seseorang akan lebih bijaksana, inklusif, toleran, dan humanis sebagaimana menjadi karakter yang dimiliki orang-orang moderat (Yunus, 2018: 188).

Dengan demikian pendidkan Islam moderat dianggap mampu mendudukan keadilan diatas tantangan zaman global, serta menjadi penyeimbang yang sangat berarti. Dengan mengimplementasikan pendidikan Islam moderat dan bertindak rasional, diyakini dapat mencegah, menangkal, atau me 0nanggulangi bebagai macam tantangan yang muncul di masa depan. Seperti ancaman radikalisme dan ekstrimisme di tengah masyarakat (Alam, 2017: 25).

Tantangan pendidikan Islam di masa depan merupakan suatu kondisi yang sudah tidak bisa dihindarkan, seiring berkembangnya era globalisasi yang merupakan suatu keadaan yang tercipta sebagai akibat dari faktor moderenisasi. Kondisi seperti ini harus dihadapi dan dilalui agar tercapainya suatu keberhasilan. Tantangan ini tidak harus disikapi sebagai sesuatu yang membuat sulit, atau kadang dapat menghambat sesuatu yang ingin dicapai, justru dengan tantangan ini harus dijadikan sebagai penggugah tekad untuk meningkatkan kualitas dan kemampuan dalam menyelesaikan sebuah masalah. Akhirnya, di masa depan perlu ada rekontruksi pendidikan agama secara umum, dan terlebih pendidikan Islam secara khusus. Rekonstruksi ini harus dimulai dari upaya pembaruan pemikiran keagamaan. Landasan utama pembaruan pemikiran keagamaan bagi penulis tentu berada pada domain sistem pendidikan agama. Pendidikan agama menjadi penting untuk segera diformulasi ulang visi pengajarannya, nilai-nilai Tawasuth (Moderat), Tasamuh (Toleransi), Tawaazun (Seimbang), Wathoniyah wa Muwathonah (Materi Kebangsaan). Karena peserta didik memerlukan semangat beragama yang inklusif. Beragama yang tidak hanya mengedepankan emosi keagamaan yang fanatik buta. Tetapi lebih kepada penguatan mental semangat keagamaan yang inklusif dan pluralis. Peserta didik juga diarahkan untuk senantiasa 
menegakkan nilai kemanusiaan yang selalu menghargai kemajemukan (Yunus, 2018: 188).

\section{Kesimpulan}

Sikap moderat dapat tercermin dalam karakter sebagai berikut; 1) penyebaran ajaran Islam melalui ideologi non kekerasan, 2) mengadopsi cara hidup modern dengan segala derivasinya, termasuk teknologi, demokrasi, HAM, dan sejemisnya, 3) penggunaan cara berpikir rasional, 4) memahami Islam dengan pendekatan kontekstual, dan 5) penggunaan ijtihad dalam mencari solusi terhadap persoalan yang tidak ditemukan justifikasinya dalam al-Quran dan hadits. Untuk menopang konsep dan sikap moderat, setidaknya ada empat prinsip dasar yang harus dikembangkan dan diinternalisasikan melalui proses pendidikan. Keempat nilai dasar tersebut ialah toleransi (tasamuh), keadilan (i'tidal), keseimbangan (tawazzun), dan persamaan. Semakin masifnya penyebaran gerakan-gerakan radikal dalam beragama menjadi tantangan nyata bagi umat Islam di Indonesia yang secara sosio kultural memiliki paham Islam moderat. Dalam konteks pendidikan, tentu mejadi tugas bersama untuk membendung radikalisasi agama (Islam) yang terjadi di Lembaga pendidikan sekaligus menyebarluaskan nilai moderasi Islam yang sesuai dengan karakter Islam Indonesia kepada para peserta didik. Ada tiga tantangan utama yang kini dihadapi oleh pendidikan Islam, yaitu kemajuan iptek, demokratisasi, dan dekadensi moral. Ketiga tantangan ini membawa pengaruh besar dalam semua bidang kehidupan manusia, termasuk bidang pendidikan. Perkembangan dan kemajuan iptek prinsipnya berpotensi melemahkan daya mental spiritual. Permasalahan baru yang harus segera diselesaikan oleh pendidikan Islam adalah dehumanisasi pendidikan dan netralisasi iptek dari nilai-nilai agama. Pendidikan Islam ditantang untuk membuktikan kemampuannya dalam penguasaan iptek, sekaligus kesanggupannya dalam mengendalikan dampak negatif dari iptek.

\section{DAFTAR PUSTAKA}

Alam, Masnur, 2017. Studi Implementasi Pendidikan Islam Moderat dalam Mencegah Ancaman Radikalisme di Kota Sungai Penuh Jambi. Jurnal Islamika, Volume 17, No. 02.

Al-Qardhawy, Yusuf. 1997. Wasathiyah Islam. Islam Moderate Legislation for Progressive Nation. Terj. Ahmad Umar Hisyam dan Muhammad Higab. Cairo: Al-Azhar.

Azra, Azyumardi. 1999. Pendidikan Islam: Tradisi dan Moderenisasi Menuju Millenium Baru. Cet. 1; Jakarta: Logos Wacana Baru.

Daulay, Haidar Putra. 2004. Pendidikan Islam dalam Sistem Pendidikan Nasional.

Cet. 1; Jakarta: Kencana. 
Fransisca, Malia. 2019. Moderat Antar Umat, Organisasi, dan Pendidikam. JUSPI (Jurnal Sejarah Peradaban Islam). Volume. 03. No. 01.

Hanafi, M.M. 2013. Moderasi Islam: Menangkal Radikalisasi berbasis Agama. Jakarta: Ikatan Alumni Al-Azhar Mesir Cabang- Cairo.

Hermawan, M.A. 2020. Nilai Moderasi Islam dan Internalisasinya di Sekolah. Jurnal Insania. Volume. 25. No. 01. Jan-Juni.

Hilmy, Masdar. 2013. “Whither Indonesia's Islamic Moderatism? A Reexamination on the Moderate Vision of Muhammadiyah and NU" dalam Journal of Indonesian Islam, Vol. 07, Number 01, June.

Mastuhu, 1999. Memberdayakan Sistem Pendidikan Islam. Cet. 2;Jakarta: Logos Wacana Ilmu.

Mubarok, Ahmad Agis. 2018. Islam Nusantara: Moderasi Islam di Indonesia. Journal of Islamic Studies and Humanities. Volume. 03. No. 02.

Pewangi, Mawardi. t.t. Tantangan Pendidikan Islam di Era Globalisasi. Jurnal Tarbawi. Volume 01. No. 01.

Rahim, Husni. 2001. Arah Baru Pendidikan Islam di Indonesia. Cet. 1; Jakarta: Logos Wacana Ilmu.

Suharto, Toto. 2017. Indonesianisasi Islam: Penguatan Islam Moderat Dalam Lembaga Pendidikan Islam di Indonesia. Al-Tahrir, Vol. 17. No. 01.

Yunus. 2018. Eksistensi Moderasi Islam dalam Kurikulum Pembelajaran PAI di SMA. Al-Tadzkiyyah: Jurnal Pendidikan Islam. Volume. 09. No. 02.

Zamimah, Iffati. 2018. Moderatisme Islam dalam Konteks Keindonesiaan (Studi Penafsiran Islam Moderat M. Quraish Shihab). Jurnal Vol. 01. No. 01.

Zubaedi. 2012. Isu-isu Baru dalam Diskursud Filsafat Pendidikan Islam dan Kapita Selekta Pendidikan Islam. Cet. I; Yogyakarta: Pustaka Pelajar. 